КРАСНОВ О. О. (ПВІЗТ ПАТ «Укрзалізниця»), ЯГУП В. Г., д. т. н., професор (ХНУМГ імені О. М. Бекетова), БОЖКО В. В., к. т. н., с. н. с. (ПВІЗТ ПАТ «Укрзалізниця»)

\title{
Активний тяговий перетворювач 3 широтно-імпульсною модуляцісю для електровоза змінного струму 3 колекторними тяговими двигунами
}

3 метою підвищення енергетичної ефективності електровозів змінного струму з колекторними тяговими двигунами розроблено силову схему і алгоритм управління активного тягового перетворювача з двозонним регулюванням напруги і широтно-імпульсною модуляцією. Результати комп'ютерного моделювання показали можливість підвищення коефіцієнта потужності електровоза 2 ЕЛ5 з новим перетворювачем до 0,99 при несинусоїдальності струму в контактній мережі THDi до $13 \%$.

Ключові слова: електровоз змінного струму, активний тяговий перетворювач, коефіцієнт потужності, широтно-імпульсна модулячія.

\begin{abstract}
Вступ
Основу парку електровозів змінного струму залізниць України складають електровози 3 колекторними тяговими двигунами постійного струму і тяговими перетворювачами, побудованими на діодах або тиристорах. При діодних випрямлячах регулювання випрямленої напруги здійснюється ступінчатим способом за рахунок перемикання секцій вторинної обмотки трансформатора. Тиристорні перетворювачі забезпечують плавне зонно-фазове регулювання напруги 3 можливістю переведення електровоза в режим рекуперативного гальмування [1].

Разом 3 тим, найбільшим недоліком діодних або тиристорних схем $є$ низький коефіцієнт потужності електровоза. У залежності від навантаження, конфігурації і параметрів системи тягового електропостачання, його величина в режимі тяги становить $0,65 \ldots 0,85$ [2] при рекомендованому значенні не менше 0,95 [3]. Коефіцієнт потужності електровоза 3 тиристорним перетворювачем в режимі рекуперації - 0,45...0,65 [4]. Наслідком цього $\epsilon$ підвищене споживання реактивної потужності тяговим навантаженням.
\end{abstract}

Основними причинами зниження коефіцієнта потужності $є$ [3-5]:

- високий реактивний опір системи електропостачання i тягового трансформатора електровоза, що обумовлює необхідність відкривання тиристорів з кутом затримки $(9 \pm 2)^{\circ}$;

- генерація тяговими перетворювачами гармонік частотою $150 \ldots 1000$ Гц в результаті процесів комутації тиристорів;

(C) О. О. Краснов, В. Г. Ягуп, В. В. Божко, 2018
— коливання напруги 3 частотою 750...1950 Гц на струмоприймачі електровоза в результаті перехідних процесів в системі «тягова мережа електровоз»;

- несинусоїдальна форма струму електровоза внаслідок індуктивного характеру навантаження та інших причин.

Відомо, що серед усіх типів високовольтних перетворювачів найкращі енергетичні показники забезпечують активні перетворювачі на повністю керованих напівпровідникових приладах [6]. Тому задача дослідження режимів роботи такого перетворювача 3 тяговим двигуном постійного струму являє інтерес $з$ теоретичної та практичної точки зору.

\section{Аналіз останніх досліджень та публікацій}

Серед значної кількості робіт, присвячених проблемі підвищення коефіцієнта потужності електровозів змінного струму, можна виділити кілька основних напрямків дослідження:

1) зменшення фазового зсуву між напругою та струмом електровоза шляхом підключення пасивного компенсатора реактивної потужності в коло вторинної обмотки тягового трансформатора. Такий компенсатор може бути дволанковим [3] або одноланковим [7]. У режимі роботи з компенсатором коефіцієнт потужності електровоза збільшується до 0,92, а в окремих випадках і до 0,97. При цьому дещо покращується форма напруги на струмоприймачі за рахунок зменшення 3-ї, 5-ї та 7-ї гармоніки;

2) удосконалення алгоритмів управління без принципової зміни силової схеми електровоза. Такими алгоритмами є одночасна комутація тиристорів [4] та різнофазне управління паралельно ввімкненими 
перетворювачами із увімкненням у коло випрямленого струму діодного розрядного плеча [8]. Випробування модернізованого перетворювача на електровозі показали зменшення питомих витрат електроенергії на 7,6 \%, а коефіцієнт потужності в номінальному режимі збільшився до 0,88 [9];

3) застосування гібридного фільтра, в якому пасивний LC-фільтр забезпечує компенсацію реактивної потужності, компенсацію 3-ї гармоніки напруги, і частково 5-ї та 7-ї гармонік. Активний фільтр компенсує всі інші вищі гармоніки напруги. Відомо кілька варіантів таких фільтрів, в тому числі з плавним регулюванням реактивної потужності компенсатора [2]. За результатами досліджень, коефіцієнт потужності електровоза ВЛ85 при обладнанні гібридним фільтром збільшується до 0,996 в режимі тяги і до 0,985 в режимі рекуперації [3];

4) останнім часом розвивається напрямок, пов'язаний 3 розробкою активних тягових перетворювачів. Алгоритмом управління IGBTтранзисторами може бути модифіковане зонно-фазове регулювання, запропоноване в $[5,8,10]$ для електровозів ВЛ80Р і 2ЭС5К, або широтно-імпульсна модуляція (ШІМ) при різних варіантах структур систем автоматичного управління. Випрямлячі з ШІМ [11-13] розглядають, в основному, як активні фільтри. Крім того, на їх базі можлива реалізація регуляторів випрямленої напруги, але цей напрямок, на наш погляд, сьогодні є дослідженим недостатньо.

\section{Мета і задачі дослідження \\ Метою цього дослідження $є$ підвищення енергетичної ефективності електровозів змінного струму 3 колекторними тяговими двигунами за рахунок використання в електроприводі активних тягових перетворювачів (АТПр).}

Для досягнення поставленої мети необхідно вирішити такі задачі:

- розробити силову схему активного тягового перетворювача 3 двозонним регулюванням випрямленої напруги i широтно-імпульсною модуляцією, а також алгоритм його управління;

- провести дослідження електромагнітних процесів та оцінити за обраними критеріями енергетичну ефективність запропонованого тягового перетворювача;

— визначити напрямки подальших досліджень активних тягових перетворювачів електровозів змінного струму.

\section{Схема i принцип роботи активного тягового перетворювача}

Враховуючи особливості роботи тягових електроприводів магістральних електровозів змінного струму 3 колекторними тяговими двигунами, можна сформулювати загальні задачі управління такими електроприводами:

— реалізація заданої сили тяги та швидкості руху електровоза шляхом регулювання випрямленої напруги двигуна (режим тяги);

— реалізація заданої гальмівної сили та швидкості руху електровоза шляхом регулювання та інвертування випрямленої напруги в контактну мережу (режим рекуперації).

Виходячи 3 цього до тягового перетворювача електровоза змінного струму можна сформулювати ряд основних вимог:

- можливість реалізації випрямного та інверторного режимів роботи;

— по можливості одноступінчате перетворення електроенергії;

- високі енергетичні показники при мінімальних втратах енергії в елементах перетворювача.

Активний тяговий перетворювач пропонується розробити на базі двозонної схеми активного випрямляча струму з розрядним діодом. Схему такого перетворювача подано на рис. 1. Будемо розглядати випадок живлення від АТПр одного двигуна $M$, що дозволить реалізувати індивідуальне регулювання сили тяги.

Конфігурація i параметри тягового трансформатора i тягового двигуна відповідають вантажному електровозу 2ЕЛ5. АТПр підключається до виводів al, 2, xl вторинної обмотки тягового трансформатора. Напруга секцій $a 1-2$ і 2-xl складає $U_{21}=U_{22}=630$ В. Додатний напрямок е. p. с. секцій вторинної обмотки трансформатора $E_{21}, E_{22}$ i e.p. с. якоря тягового двигуна $E_{d}$ на рис. 1 показано суцільною стрілкою, від'ємний напрямок штриховою. На вході АТПр встановлено буферні конденсатори $C_{21}, C_{22}$. Пульсації випрямленого струму $I_{d}$ згладжуються реактором $L_{\mathrm{p}}$.

АТПр має шість плечей, кожне з яких складається 3 послідовно ввімкнених транзистора i діода (відповідно VT1-VT6 і VD1-VD6). Розрядний діод $V D 0$ підключається до навантаження через транзистор $V T 7$ і діод VD7. У режимі тяги транзистор VT7 постійно знаходиться у відкритому стані.

Полярність випрямленої напруги $U_{d}$ в режимі тяги вказана на рис. 1 без дужок. Випрямлена напруга імпульсної форми утворюється шляхом подачі

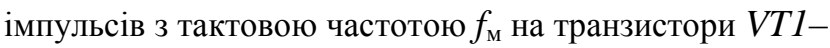
VT6 відповідно до алгоритму, наведеного в табл. 1. При цьому $U_{2}-$ вхідна змінна напруга АТПр. Перетворювач працює в режимі широтно-імпульсної модуляції. На інтервалах паузи коло випрямленого струму замкнене на розрядний діод $V D O$, а струм в колі підтримується за рахунок енергії, запасеної в індуктивності. 


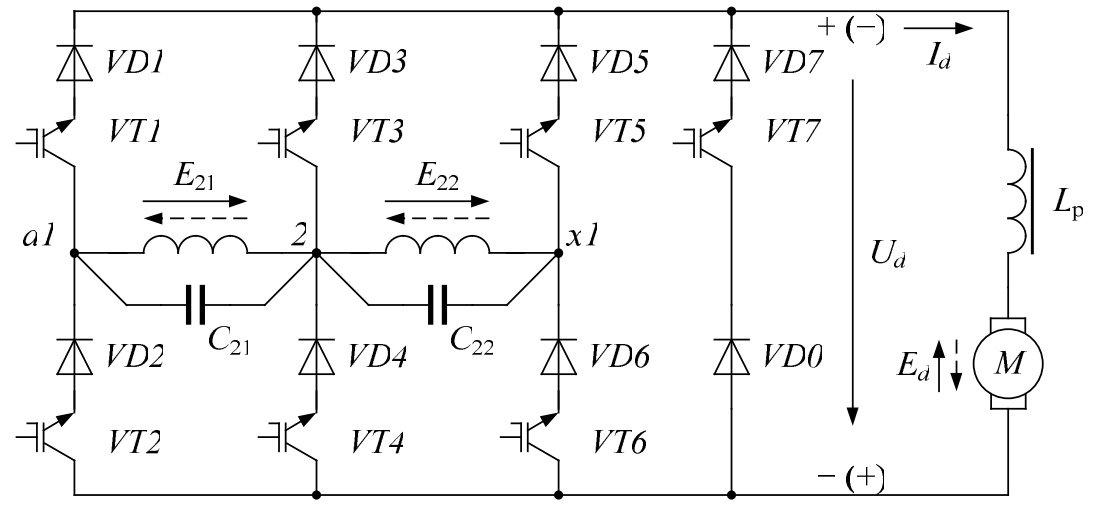

Рис. 1. Принципова схема активного тягового перетворювача з двозонним регулюванням випрямленої напруги

Плавне регулювання випрямленої напруги $U_{d}$ здійснюється шляхом зміни коефіцієнта модуляції $\mu$. На 1-й зоні ступені регулювання $3 \mu \approx 0,3 \ldots 0,5$ використовується лише при пуску в короткочасних режимах роботи. На 2-й зоні регулювання починається $3 \mu \approx 0,5$.

Таблиця 1

Алгоритм управління АТПр

\begin{tabular}{|c|c|c|c|c|}
\hline Режим & $\begin{array}{l}\text { Зона } \\
\text { регулю- } \\
\text { вання }\end{array}$ & $\begin{array}{l}U_{2}, \\
\mathrm{~B}\end{array}$ & $\begin{array}{l}\text { Полярність } \\
\text { напруги } \\
U_{2}\end{array}$ & $\begin{array}{l}\text { Номери } \\
\text { плечей } \\
\text { АТПр }\end{array}$ \\
\hline \multirow{4}{*}{ Тяга } & \multirow{2}{*}{1} & \multirow{2}{*}{630} & + & $V T 4, V T 5$ \\
\hline & & & - & VT3, VT6 \\
\hline & \multirow{2}{*}{2} & \multirow{2}{*}{1260} & + & $V T 2, V T 5$ \\
\hline & & & - & $V T 1, V T 6$ \\
\hline \multirow{4}{*}{ Рекуперація } & \multirow{2}{*}{2} & \multirow{2}{*}{1260} & + & $V T 1, V T 6$ \\
\hline & & & - & $V T 2, V T 5$ \\
\hline & \multirow{2}{*}{1} & \multirow{2}{*}{630} & + & VT3, VT6 \\
\hline & & & - & $V T 4, V T 5$ \\
\hline
\end{tabular}

При переході до рекуперативного гальмування тяговий двигун $M$ переводять в генераторний режим шляхом перемикання обмотки якоря таким чином, щоб напрямок е.р. с. якоря $E_{d}$ збігався 3 напрямком випрямленого струму $I_{d}$. Цей принцип не відрізняється від прийнятого на електровозах ВЛ85, 2ЭС5К, 2ЕЛ5.

Полярність випрямленої напруги $U_{d}$ в режимі рекуперації вказана на рис. 1 в дужках, а напрямок випрямленого струму $I_{d}$ залишається незмінним. Коло випрямленого струму замикається на діод $V D O$ тільки на інтервалах паузи. Для цього використовується транзистор VT7, який також перемикається 3 тактовою частотою модуляції $f_{\text {м. }}$.

Реалізація рекуперації на електровозах змінного струму відрізняється складністю. Розробка АТПр на повністю керованих напівпровідникових приладах при управлінні методом ШІМ обумовлює необхідність розробки i дослідження випрямної установки збудження, побудованої за схожими принципами [5].
Оскільки ця тема потребує окремого дослідження, у подальшому розглянемо тільки режим тяги.

Будемо враховувати, що на чотиривісній секції електровоза встановлюється чотири АТПр. До однієї тягової обмотки трансформатора (наприклад, al-xl) підключається паралельно два АТПр, при цьому батарея буферних конденсаторів $C_{21}-C_{22} \epsilon$ спільною для двох перетворювачів.

\section{Алгоритм широтно-імпульсної модуляції}

Для управління активним тяговим перетворювачем пропонується застосувати алгоритм широтноімпульсної модуляції 3 прямокутно-ступінчатим модуляційним сигналом. Імпульси управління транзисторами (рис. 2) характеризуються комутаційною функцією $s^{*}$ і формуються в моменти рівності опорної пилкоподібної напруги $u_{\text {оп }}$ i модуляційного сигналу $u_{\mathrm{M}}$. Частоту модуляції прийнято $f_{\mathrm{M}}=1200$ Гц, при цьому частота мережі $f=50$ Гц.

Прямокутно-ступінчатий сигнал $є$ апроксимацією синусоїди і має такі параметри [14]: $\theta_{i}$ - фазовий кут $i$-ї сходинки; $\Delta \theta-$ дискретний крок зміни фазового кута; $i=1 \ldots n-$ номер сходинки; $n-$ кількість сходинок; $\tau_{1}$ і $\tau_{0}$ - відповідно відносна тривалість імпульсу та паузи; $\mu-$ коефіцієнт модуляції. Ці параметри можна визначити за формулами

$n=\frac{f_{\grave{\mathrm{i}}}}{2 f}$,

$\Delta \theta=180^{\circ} / n$

$\theta_{i}=i \cdot \Delta \theta$,

$\tau_{1}=\left\{\begin{array}{l}(0 \leq \theta \leq \pi / 2) \rightarrow \mu \cdot \sin \theta \\ (\pi / 2<\theta \leq \pi) \rightarrow \mu \cdot \sin (\theta-\Delta \theta)\end{array}\right.$,

$\tau_{0}=1-\tau_{1}$. 


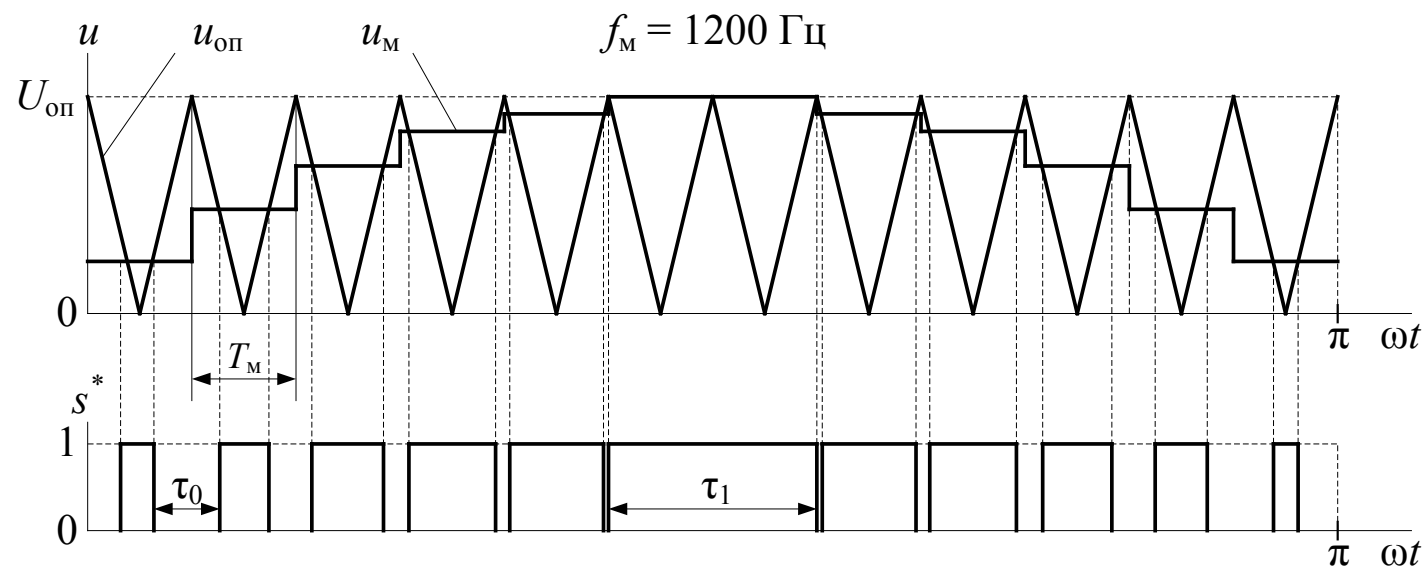

Рис. 2. Діаграми формування імпульсів ШІМ

Опорна пилкоподібна напруга $u_{\text {оп }}$ і модуляційний сигнал $u_{\mathrm{M}}\left(U_{\text {оп }}\right.$ - амплітуда опорної напруги):

$$
\begin{aligned}
& u_{\text {on }}(t)=\frac{U_{o n}}{\pi} \mid \arcsin \left[\sin \left(\frac{\omega_{\mathcal{M}}}{2} t+\frac{\pi}{2}\right)\right], \\
& u_{\mathrm{M}}(\theta)=\left\{\begin{array}{l}
\left(0 \leq \theta \leq \theta_{1}\right) \rightarrow \tau_{1}\left(\theta_{1}\right) \\
\left(\theta_{1} \leq \theta \leq \theta_{2}\right) \rightarrow \tau_{1}\left(\theta_{2}\right) . \\
\cdots \\
\left(\theta_{i-1} \leq \theta \leq \theta_{i}\right) \rightarrow \tau_{1}\left(\theta_{i}\right)
\end{array}\right.
\end{aligned}
$$

При постійній частоті ШІМ параметри імпульсів та пауз можуть бути записані в пам'ять мікроконтролера в індексному або табличному вигляді [14]. Це дозволить не використовувати в системі управління генератори модуляційного та опорного сигналів, i таким чином знизити обчислювальну потужність системи. Залежно від структури системи управління в пам'ять можуть бути записані значення часу подачі імпульсів на транзистори АТПр $\left(t_{\alpha} ; t_{\beta}\right)$ або кутів відкривання і закривання транзисторів $\left(\alpha_{i} ; \beta_{i}\right)$.

Розрахункові формули для вказаних параметрів ШІМ отримаємо 3 таких міркувань. На періоді повторюваності $T=0 \ldots \pi \in n$ періодів модуляції $T_{\mathrm{M}}$ (див. рис. 2). Тоді $T=n T_{\mathrm{M}}$. На кожному періоді $T_{\mathrm{M}}$ відносна тривалість відкриття ключа дорівнює $\tau_{1}$. Тому тривалість імпульсу на $i$-му періоді модуляції, $\mathrm{t}_{1 i}, \mathrm{c}$,

$$
t_{1 i}=\frac{T}{n} \tau_{1 i}
$$

Час подачі $t_{\alpha}$ і завершення $t_{\beta} i$-го імпульсу, с,

$$
\begin{aligned}
& t_{\alpha}=\frac{T}{n}(i-1)+\frac{T}{2 n}\left(1-\tau_{1 i}\right), \\
& t_{\beta}=\frac{T}{n}(i-1)+\frac{T}{2 n}\left(1-\tau_{1 i}\right)+\frac{T}{n} \tau_{1 i} .
\end{aligned}
$$

3 урахуванням коефіцієнта модуляції $\tau_{1 i}=\mu \tau_{11 i}$, де $\tau_{11 i}$ - відносна тривалість $i$-го імпульсу при $\mu=1$. Тоді кути $\alpha_{i}$ і $\beta_{i}$ в радіанах

$$
\begin{aligned}
& \alpha_{i}=2 \pi f t_{\alpha}=\frac{2 \pi}{n}\left[(i-1)+\frac{1}{2}\left(1-\mu \tau_{11 i}\right)\right] \\
& \beta_{i}=2 \pi f t_{\beta}=\frac{2 \pi}{n}\left[(i-1)+\frac{1}{2}\left(1-\mu \tau_{11 i}\right)+\mu \tau_{11 i}\right]
\end{aligned}
$$

Середнє значення випрямленої напруги АТПр у випадку іiі регулювання методом однополярної ШІМ без урахування втрат напруги і пульсацій (при $C=\infty$ ) при $f_{\text {м }}=1200$ Гц можна знайти за формулою [6]

$U_{d}=\frac{\sqrt{2} \mu U_{2}}{\pi}\left[2\left(\cos \alpha_{1}-\cos \beta_{1}+\ldots+\cos \alpha_{6}-\cos \beta_{6}\right)\right]$,

де $U_{2}$ - діюче значення напруги відповідної секції вторинної обмотки трансформатора;

$\alpha_{1} \ldots \alpha_{6}$ і $\beta_{1} \ldots \beta_{6}$ - відповідно кути відкривання і закривання транзисторів при $\mu=1$;

$n=1 \ldots 6-$ номер імпульсу.

Результати розрахунку номінальної випрямленої напруги за формулою (13) в режимі тяги подано в табл. 2. 
Розрахунок номінальної випрямленої напруги АТПр $\left(f_{\mathrm{m}}=1200\right.$ Гц $)$

\begin{tabular}{|c|c|c|c|c|c|c|c|c|c|}
\hline \multirow{2}{*}{ Зона } & \multirow{2}{*}{$U_{2}, \mathrm{~B}$} & \multicolumn{7}{|c|}{$U_{d}, \mathrm{~B}$, при коефіцієнті модуляції $\mu$} \\
\cline { 3 - 10 } & & 0,3 & 0,4 & 0,5 & 0,6 & 0,7 & 0,8 & 0,9 & 1,0 \\
\hline 1 & 630 & 143,4 & 191,2 & 238,9 & 286,7 & 334,5 & 382,3 & 430,1 & 477,9 \\
\hline 2 & 1260 & - & - & 477,9 & 573,5 & 669,0 & 764,6 & 860,2 & 955,8 \\
\hline
\end{tabular}

\section{Моделювання електровоза в режимі тяги}

Моделювання електровоза 3 АТПр в режимі тяги виконувалось в програмному пакеті MATLAB при таких умовах [15]: напруга на шинах тягової підстанції $U_{\text {тп }}=25 \mathrm{\kappa}$, одноколійна електрифікована ділянка довжиною 10 км 3 одностороннім живленням, електровоз знаходиться на кінці ділянки. Працює вісім тягових двигунів (дві секції). Маса поїзда 2500 т. Швидкість руху поїзда: $3 \ldots 25$ км/год (1 зона), 25...52 км/год (2 зона).

Оцінка енергоефективності АТПр при віртуальних експериментах була проведена шляхом визначення таких показників: коефіцієнт потужності електровоза, виміряний в колі первинної обмотки тягового трансформатора $\left(K_{\mathrm{M}}\right)$, коефіцієнти спотворення синусоїдальності кривої напруги на струмоприймачі $u_{1}$ $\left(K_{U}, \%\right)$ і струму первинної обмотки трансформатора електровоза $i_{1}\left(K_{I}, \%\right)$, коефіцієнт спотворення струму $v_{l}$, коефіцієнти $k$-х гармонічних складових напруги $\left(K_{U k}, \%\right)$ і струму $\left(K_{I k}, \%\right)$.

Коефіцієнт потужності електровоза $K_{\mathrm{M}}$ був розрахований за формулою

$K_{\mathrm{M}}=P_{1} / U_{1} I_{1}=\left(\int_{0}^{T} u_{1} i_{1} d t\right) / \sqrt{\left(\int_{0}^{T} u_{1}^{2} d t\right)\left(\int_{0}^{T} i_{1}^{2} d t\right)}$,

де $P_{1}, U_{1}, I_{1}$ - відповідно потужність та діючі значення напруги та струму первинної обмотки трансформатора; $u_{1}, i_{1}$ - відповідно миттєві значення напруги та струму первинної обмотки трансформатора.

Коефіцієнт спотворення струму первинної обмотки тягового трансформатора $є$ відношенням діючого значення 1-ї гармоніки струму $I_{1(1)}$ до діючого значення всього струму $I_{1}$

$v_{I}=I_{1(1)} / I_{1}$

Результати комп'ютерного моделювання при $\mu=0,5$ і $\mu=1,0$ наведені в табл. 3. Осцилограми напруги та струму електровоза 3 АТПр в режимі тяги на 2 зоні регулювання подано на рис. 3 .

Таблиця 3

Результати моделювання електровоза з АТПр

\begin{tabular}{|l|c|c|c|c|c|}
\hline \multirow{2}{*}{$\begin{array}{l}\text { Найменування } \\
\text { параметрів }\end{array}$} & Познач., & \multicolumn{2}{c|}{1 зона } & \multicolumn{2}{c|}{2 зона } \\
\cline { 5 - 6 } & од. вим. & $\mu=0,5$ & $\mu=1,0$ & $\mu=0,5$ & $\mu=1,0$ \\
\hline Напруга на струмоприймачі & $U_{1}, \mathrm{\kappa B}$ & 25,00 & 24,94 & 25,00 & 24,63 \\
\hline $\begin{array}{l}\text { Струм первинної обмотки трансформатора } \\
\text { електровоза }\end{array}$ & $I_{1}, \mathrm{~A}$ & 54,4 & 75,9 & 83,8 & 151,2 \\
\hline Коефіцієнт потужності електровоза & $K_{\mathrm{M}}$ & 0,932 & 0,972 & 0,964 & 0,991 \\
\hline $\begin{array}{l}\text { Коефіцієнт спотворення синусоїдальності } \\
\text { кривої напруги } u_{1}\end{array}$ & $K_{U}, \%$ & 4,90 & 2,58 & 9,42 & 5,75 \\
\hline $\begin{array}{l}\text { Коефіціснт спотворення синусоїдальності } \\
\text { кривої струму } i_{1}\end{array}$ & $K_{I}, \%$ & 10,73 & 9,35 & 12,55 & 9,68 \\
\hline Коефіціснт спотворення струму $i_{1}$ & $v_{I}$ & 0,9943 & 0,9957 & 0,9922 & 0,9953 \\
\hline Випрямлена напруга & $U_{d}, \mathrm{~B}$ & 233 & 465 & 471 & 922 \\
\hline Струм тягового двигуна & $I_{d}, \mathrm{~A}$ & 1014 & 737 & 755 & 732 \\
\hline Сила тяги електровоза & $F_{\mathrm{K}}, \mathrm{\kappa H}$ & 561 & 367 & 379 & 363 \\
\hline
\end{tabular}

3 теоретичної та практичної точки зору являє інтерес залежність коефіцієнта потужності електровоза від випрямленої напруги. Ця залежність отримана при зміні коефіцієнта модуляції $\mu=0,3 \ldots 1$ (1 зона), $\mu=0,55 \ldots 1 \quad$ (2 зона) $\quad$ і показана на рис. 4 (крива 1). Для порівняння на цьому ж рисунку наведено залежність $K_{\mathrm{M}}=f\left(U_{d}\right)$ для електровоза 2 ЕЛ5 (крива 2) 3 тиристорним випрямно-інверторним перетворювачем (ВIП), отриману за умов: 1-4 зона регулювання, кути відкривання тиристорів $\alpha_{0}=9^{\circ}$; $\alpha_{\mathrm{p}}=13 \ldots 165^{\circ}$. 
Ud, Id

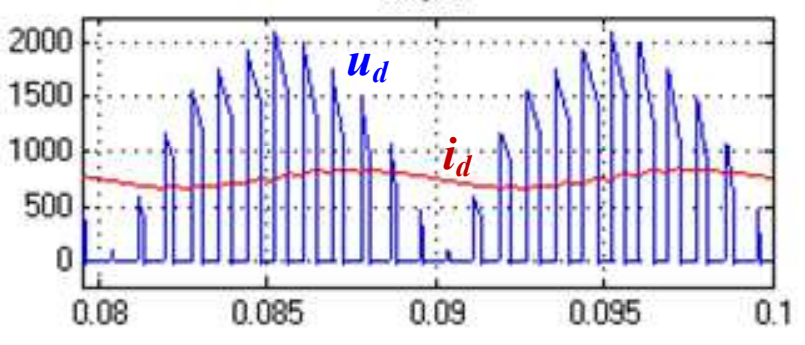

U2, IV
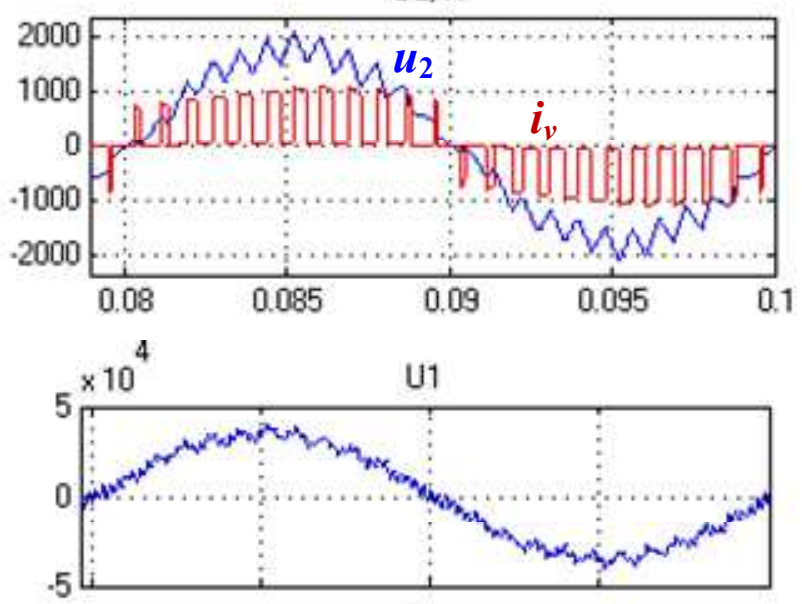

11

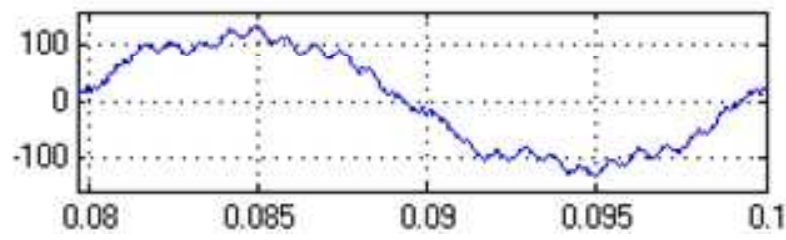

a
Ud, Id

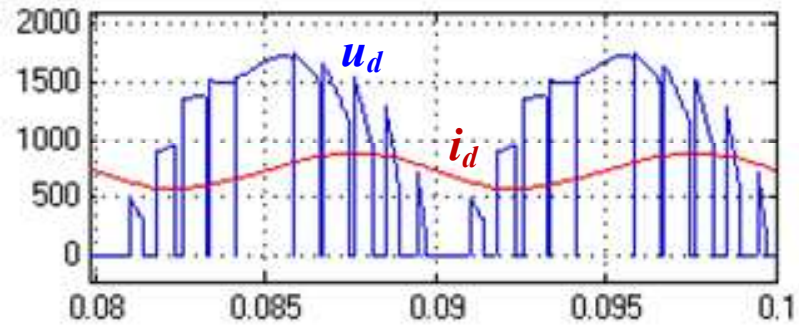

U2. IV

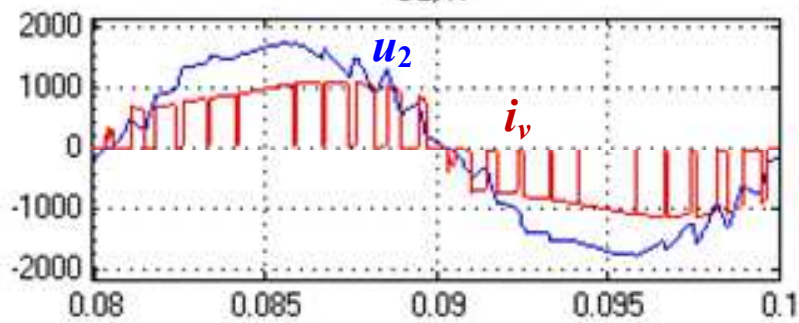

U1

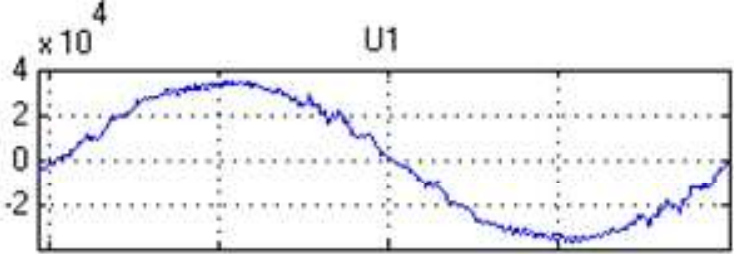

11

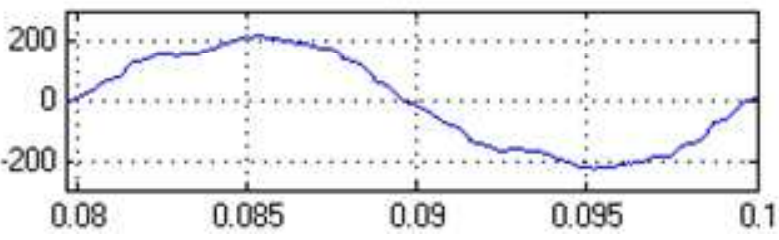

б

Рис. 3. Осцилограми напруги та струму електровоза з АТПр на 2 зоні: $\mathrm{a}-\mu=0,5 ; \sigma-\mu=1,0 ; u_{d}, i_{d}-$ випрямлені напруга і струм;

$u_{2}$ — напруга вторинної обмотки трансформатора; $i_{v}$ - вхідний струм АТПр;

$u_{1}, i_{1}$ - напруга на струмоприймачі і струм первинної обмотки трансформатора

Середній коефіцієнт потужності $K_{\mathrm{Mc}}$ у всьому діапазоні регулювання

$K_{\mathrm{Mc}}=\left(\sum_{j=1}^{m} K_{\mathrm{M} j}\right) / m$,

де $j=1 \ldots m$ - номер досліду; $m-$ кількість вимірювань.

Збільшення або зменшення середнього коефіцієнта потужності електровоза 3 АТПр відносно базового значення (ВІП) визначимо за формулою

$$
\delta_{\mathrm{KM}}=\frac{K_{\mathrm{Mc}}^{\mathrm{AT \Pi p}}-K_{\mathrm{Mc}}^{\mathrm{BI \Pi}}}{K_{\mathrm{Mc}}^{\mathrm{BII}}} \cdot 100 \%,
$$

де $\mathrm{K}^{\mathrm{BI \Pi}}{ }_{\text {мс }}, \mathrm{K}^{\mathrm{AT \Pi р}}{ }_{\text {мс }}$ - відповідно середній коефіцієнт потужності електровоза 3 ВІП і АТПр увсьому діапазоні регулювання. 


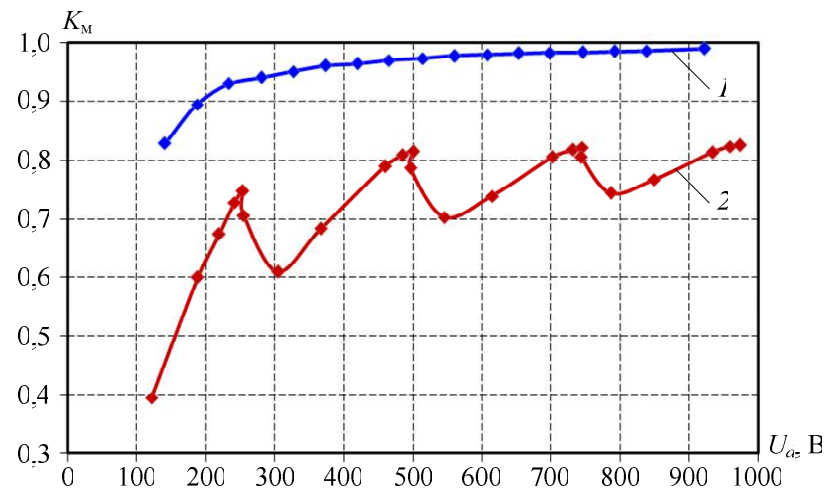

Рис. 4. Залежність коефіцієнта потужності електровоза від випрямленої напруги: 1 - АТПр; 2 - ВІП

Розрахунок за формулами (16), (17) дав такі результати: $\mathrm{K}_{\text {мс }}^{\mathrm{BI \Pi}}=0,740 ; \mathrm{K}_{\text {мс }}^{\mathrm{AT \Pi р}}=0,959 . \mathrm{Y}$ середньому коефіцієнт потужності електровоза з АТПр вище, ніж з ВІП, на $\delta_{\text {км }}=29,6 \%$. У номінальному режимі збільшення коефіцієнта потужності електровоза $з$ АТПр у порівнянні 3 ВІП становить $\delta_{\text {км }}=20 \%$.

Результати моделювання показали, що коефіцієнт спотворення синусоїдальності кривої напруги на струмоприймачі $K_{U}$ в усьому діапазоні регулювання змінюється в межах 2,58...10,63\%, коефіцієнт спотворення синусоїдальності кривої струму $K_{I}-$ 9,14...13,07 \%. При цьому, як показали досліди, $K_{U}$ на шинах 27,5 кВ тягової підстанції не перевищує $7 \%$ (гранично допустиме значення для даного класу напруги за ГОСТ 13109-97 - 8 \%).

Залежність коефіцієнта спотворення синусоїдальності кривої напруги на струмоприймачі $K_{U}$ від відстані від електровоза до тягової підстанції $s$ у номінальному режимі його роботи (2 зона, $\mu=1,0)$ наведена на рис. 5.

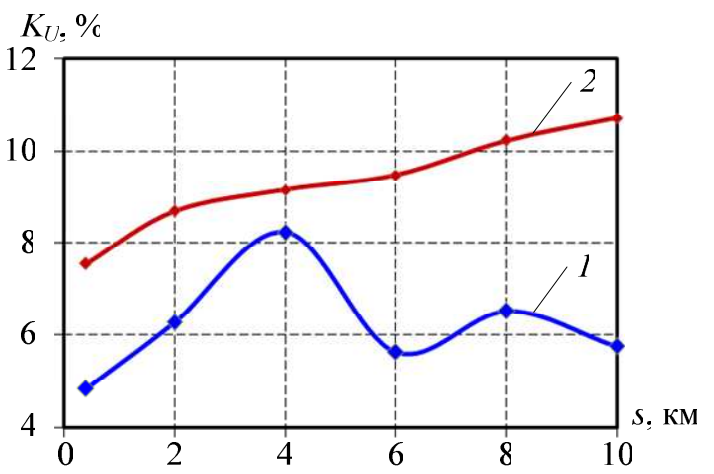

Рис. 5. Залежність коефіцієнта спотворення синусоїдальності кривої напруги на струмоприймачі від відстані від електровоза до тягової підстанції: 1 -АТПр; 2 - ВІП
Гармонічний склад напруги на струмоприймачі $u_{1}$ та струму первинної обмотки тягового трансформатора $i_{1}$ на 2 зоні регулювання наведено на рис. 6.

$K_{U k:} \%$

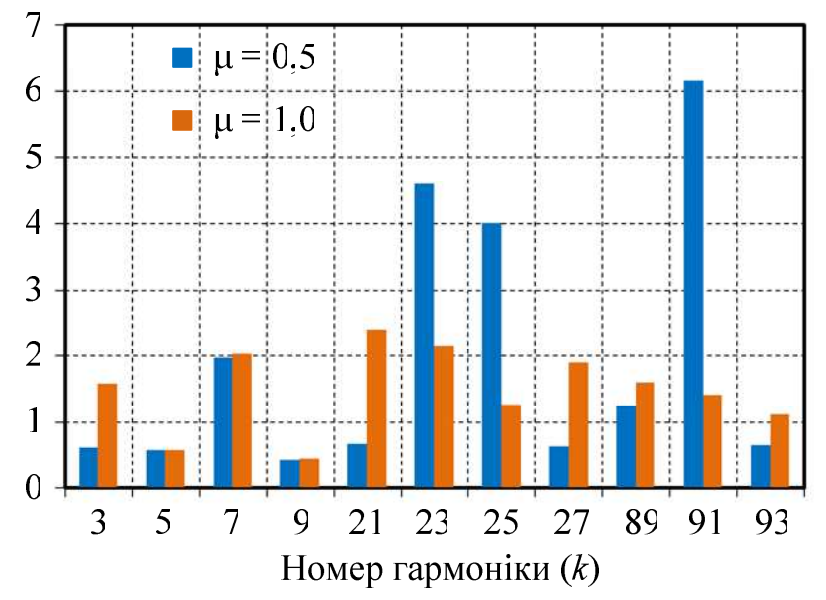

a

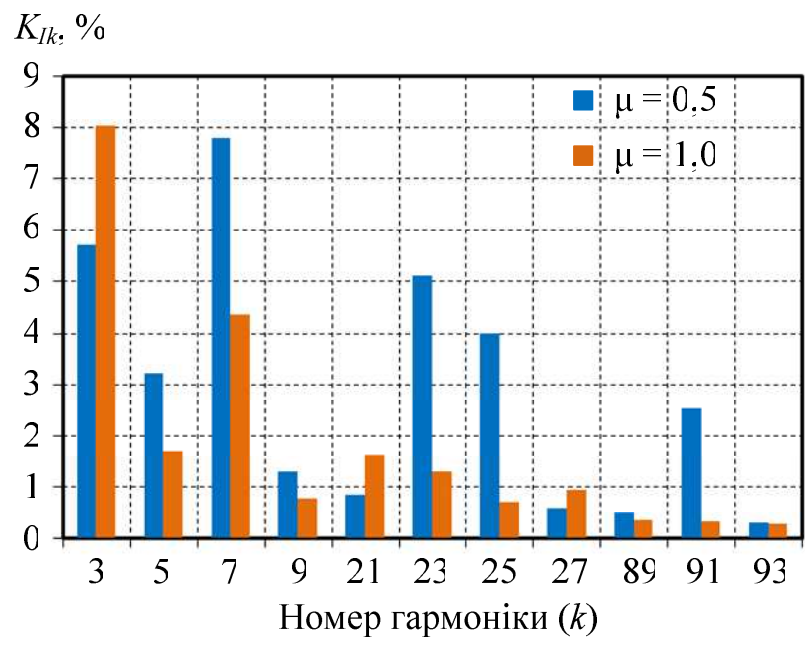

6

Рис. 6. Гармонічний склад напруги $u_{1}$ (a) та струму $i_{1}$ (б) електровоза з АТПр (2 зона регулювання)

\section{Обговорення результатів моделювання активного тягового перетворювача}

Результати експериментального дослідження активного тягового перетворювача на електровозі змінного струму 2ЕЛ5 показали, що робота АТПр характеризується такими енергетичними показниками:

1) у діапазоні регулювання $\mu=0,5 \ldots 1,0$ коефіцієнт потужності електровоза складає $0,93 . .00,97$ (1 зона) i 0,96...0,99 (2 зона). 3 рис. 4 видно, що характер зміни коефіцієнта потужності електровоза 3 АТПр і ВІП різний. Найбільший $K_{\mathrm{M}}$ при ВІП має місце на початку і в кінці зони регулювання, а в середині зони він знижується. Коефіцієнт потужності електровоза 3 
АТПр при збільшенні коефіцієнта модуляції зростає за нелінійною залежністю. Результати дослідження дозволяють стверджувати, що, 3 точки зору споживання реактивної потужності, АТПр має переваги перед тиристорним ВIП;

2) прийнятий алгоритм управління АТПр забезпечує дотримання коефіцієнта спотворення синусоїдальності кривої напруги на шинах 27,5 кВ тягової підстанції не більше $7 \%$. Оскільки дослідження проводились при синусоїдальній формі напруги джерела живлення, логічно припустити, що при несинусоїдальних спотвореннях, зумовлених роботою мережі зовнішнього електропостачання або інших електровозів на ділянці, несинусоїдальність напруги на струмоприймачі електровоза буде ще більшою. У такому випадку для дотримання показників якості електроенергії слід встановлювати додаткові активні фільтри на тягових підстанціях або на електрорухомому складі;

3) за рахунок активного формування струму коефіцієнт спотворення синусоїдальності кривої струму первинної обмотки трансформатора електровоза з АТПр складає 9...13\%, що приблизно в 2 рази менше, ніж у тиристорного ВІП $\left(K_{I}=20 \ldots 30 \%\right.$ [3]);

4) 3 точки зору гармонічного складу напруги та струму, найменш вигідним є режим при $\mu \approx 0,5 \ldots 0,6$. У цьому режимі найбільшу амплітуду мають гармоніки напруги 7, 23, 25, 91 та струму 3, 5, 7, 23, 25, 91. Зменшення коефіцієнта модуляції $3 \quad 1,0$ до 0,5 призводить до збільшення коефіцієнтів $k$-х гармонічних складових 23, 25, 91 гармонік напруги та 5, 7, 9, 23, 25, 91 гармонік струму. Слід відмітити, що детальне дослідження гармонічного складу напруги та струму електровоза 3 АТПр потребує окремого розгляду і виходить за межі даної статті.

Оскільки наявність вищих гармонічних складових в контактній мережі $\epsilon$ небажаною, подальші дослідження повинні враховувати необхідність корекції форми напруги та струму електровоза 3 АТПр. Можливими шляхами вирішення цієї проблеми $\epsilon$ застосування багаторівневої схеми випрямляча, модифікованих алгоритмів ШІМ або підключення до АТПр додаткового активного фільтра.

Слід відмітити, що модернізація існуючих серій електровозів та електропоїздів змінного струму шляхом встановлення активних тягових перетворювачів, на нашу думку, буде доцільною в умовах неможливості швидкого масового переходу локомотивного господарства залізниці на асинхронний тяговий привод. При цьому необхідно враховувати можливість продовження терміну служби модернізованого електрорухомого складу.

\section{Висновки}

1. Одним із способів підвищення енергетичних характеристик електровозів змінного струму 3 колекторними тяговими двигунами є заміна діодного або тиристорного тягового перетворювача на перетворювач на повністю керованих напівпровідникових приладах. У даній роботі запропоновано i досліджено активний тяговий перетворювач 3 двозонним регулюванням випрямленої напруги i широтно-імпульсною модуляцією за прямокутно-ступінчатим законом при частоті модуляції 1200 Гц.

2. Результати математичного моделювання і аналіз енергетичної ефективності показали, що активний тяговий перетворювач забезпечує високий коефіцієнт потужності електровоза $(0,93 \ldots 0,99)$ і більш низький рівень несинусоїдальності струму первинної обмотки трансформатора електровоза (THDi до 13\%) у порівнянні 3 тиристорним перетворювачем. Можна відмітити, що активний тяговий перетворювач при встановленні на восьмивісному електровозі змінного струму 2ЕЛ5 з колекторними тяговими двигунами дозволить забезпечити підвищення коефіцієнта потужності в номінальному режимі на $20 \%$, що дає змогу скоротити витрати електроенергії на тягу поїздів.

3. Подальші дослідження повинні бути спрямовані на корекцію форми напруги та струму електровоза 3 активним тяговим перетворювачем при ШІМрегулюванні випрямленої напруги. Цю проблему можна вирішити шляхом застосування багаторівневої схеми випрямляча, модифікованих алгоритмів ШІМ або підключення додаткового активного фільтра.

\section{Список використаних джерел}

1. Гетьман, Г. К. Теория электрической тяги [Текст]: монография. В 2 т. Т. 1 / Г.К. Гетьман. Днепропетровск: Изд-во Маковецкий, 2011. $456 \mathrm{c.}$

2. Кулинич, Ю. М. Повышение энергетической эффективности пассивного компенсатора электровоза однофазно-постоянного тока [Текст] / Ю. М. Кулинич, В. К. Духовников // Транспорт Азиатско-Тихоокеанского региона. - 2013. № $1 .-$ C. 44-50.

3. Кулинич, Ю. М. Адаптивная система автоматического управления гибридного компенсатора реактивной мощности электровоза с плавным регулированием напряжения [Текст]: монография / Ю. М. Кулинич. - Хабаровск: ДВГУПС, 2001. - $153 \mathrm{c.}$

4. Власьевский, С. В. Улучшение формы напряжения контактной сети при работе электровозов с тиристорными преобразователями [Текст] /
С. В. Власьевский,
В. Г. Скорик, 
О. В. Мельниченко // Вестник ВНИИЖТ. - 2007. 一 № 5. - C. 42-47.

5. Шрамко, С. Г. Повышение эффективности эксплуатации электровозов переменного тока в режиме рекуперативного торможения [Текст] / С. Г. Шрамко // Вестник ИрГТУ. — 2016. — № 4 (111). - C. 192-199.

6. Електроніка i мікросхемотехніка [Текст]: навч. посібник у 4-х т. Т. 4. Книга 1. Силова електроніка / В. І. Сенько та ін.; за ред. В. І. Сенька. - К. : Каравела, 2012. - 640 с.

7. Испытания системы компенсации реактивной мощности на электровозе 3ЭС5К [Текст] / А. С. Копанев, П. А. Хрипков, В. М. Волков, П. С. Вольт // Вестник ВЭлНИИ. - 2010. № 2 (60). - C. 14-36.

8. Мельниченко, О.В. Повышение энергетической эффективности тяговых электроприводов электровозов переменного тока [Текст] : дисс... д-ра техн. наук: спец. 05.09.03 «Электротехнические комплексы и системы» / О. В. Мельниченко. - Хабаровск, 2015. - 392 с.

9. Власьевский, С. В. Дальневосточный государственный университет на пути содействия инновационному развитию [Текст] / С. В. Власьевский, А. К. Пляскин, А. В. Плотников // Наука и транспорт. - 2008. - С. 58-62.

10. Яговкин, Д. А. Разработка математической модели выпрямительно-инверторного преобразователя на IGBT-транзисторах для электровоза переменного тока и его блока управления в режиме тяги [Текст] / Д.А. Яговкин // Современные технологии. Системный анализ. Моделирование. - 2015. № 3 (47). - C. 197-202.

11. Michalik, J. Single Phase Current-Source Active Rectifier for Traction: Control System Design and Practical Problems [Text] / J. Michalik, J. Molnar, Z. Peroutka // Advances in Electrical and Electronic Engineering. North America, 5 Jun. 2011. - P. 86-89.

12. Michalik, J. Active Elimination of Low-Frequency Harmonics of Traction Current-Source Active Rectifier [Text] / J. Michalik, J. Molnar, Z. Peroutka // Transactions on Electrical Engineering. - Vol. 1 (2012). - No. 1. - P. 30-35.

13. Michalik, J. Behavior of Active Current Source Rectifier under Critical Transient Conditions in Traction [Text] / J. Michalik, J. Molnar, Z. Peroutka // 15th International Power Electronics and Motion Control Conference, EPE-PEMC 2012 ECCE Europe. Novi Sad, Serbia, 2012. -6 p.

14. Стрижнев, А. Г. Синтез напряжений многократных равномерных ШИМ, созданных по ступенчатым функциям построения [Текст] / А. Г. Стрижнев, Г. В. Ледник // Энергетика... (Изв. высш. учеб. заведений и энерг. объединений СНГ). - 2010. — № 5. - С. 24-30.
15. Ягуп, В.Г. Математическое моделирование электропривода электровоза $2 Э Л 5$ в режиме тяги [Текст] / В. Г. Ягуп, А. А. Краснов // Зб. наук. праць Укр. держ. ун-ту залізнич. трансп. - Харків : УкрдУЗТ, 2017. - Вип. 170. - С. 20-31.

Краснов А. А., Ягуп В. Г., Божко В. В. Активный тяговый преобразователь с широтно-импульсной модуляцией для электровоза переменного тока с коллекторными тяговыми двигателями. С целью повышения энергетической эффективности электровозов переменного тока с коллекторными тяговыми двигателями разработана силовая схема и алгоритм управления активного тягового преобразователя с двухзонным регулированием напряжения и широтно-импульсной модуляцией. Результаты компьютерного моделирования показали возможность повышения коэффициента мощности электровоза 2ЭЛ5 с новым преобразователем до 0,99 при несинусоидальности тока в контактной сети THDi до $13 \%$.

Ключевые слова: электровоз переменного тока, активный выпрямитель тока, коэффициент мощности, широтно-импульсная модуляция.

Krasnov O., Yagup V., Bozhko V. Active traction converter with pulse-width modulation for AC electric locomotives with DC traction motors. One way to increase the energy efficiency of AC electric locomotives with DC traction motors is to use converters on fully controlled semiconductor devices. Power circuit and control algorithm of active traction converter with twozone voltage regulation are developed in this article. As an algorithm for controlling IGBT-transistors, rectangularstepped pulse width modulation with a carrier frequency of $1200 \mathrm{~Hz}$ is used. The simulation of the active traction converter is performed in MATLAB. The results of the experiments showed that the power factor of 2EL5 electric locomotive with a new converter is $0.83 \ldots 0.99$ over the entire range of loads. This is more than for a thyristor rectifier. The THDi of the contact wire current is up to $13 \%$. In further research, we must focus on finding ways to compensate for the higher harmonics of the voltage and current of an electric locomotive under PWM voltage regulation.

Key words: AC electric locomotive, active current-source rectifier, power factor, pulse-width modulation.

Надійшла 01.06.2018 p.

Краснов Олексій Олександрович, провідний науковий співробітник науково-дослідного відділу «Інфраструктура залізниць та електрична тяга». Харківське відділення філії «Прокетно-вишукувальний 


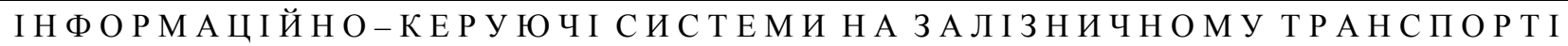

інститут залізничного транспорту» ПАТ «Укрзалізниия».E-mail: uzdlines@gmail.com.

ORCID: http://orcid.org/0000-0002-7538-8965.

Ягуп Валерій Григорович, д. т. н., професор кафедри систем електропостачання та електроспоживання міст. Харківський національний університет міського господарства імені О. М. Бекетова.

E-mail: yagup.walery@gmail.com.

ORCID:

http://orcid.org/0000-0002-7019-3499.

Божко Володимир Вячеславович, к. т. н., с. н. с., начальник науково-дослідного відділу «Інфраструктура залізниць та електрична тяга». Харківське відділення філії «Прокетно-вишукувальний інститут залізничного транспорту» ПАТ «Укрзалізниця». E-mail: bozhkovv81@ gmail.com. ORCID: http://orcid.org/0000-0001-6068-2881.
Krasnov Oleksii, Leading Researcher, Department of railway infrastructure and traction, Branch "Design and survey institute of railway transport" of Public JointStock Company "Ukrainian zaliznytsia". E-mail: uzdlines@gmail.com.ORCID: http://orcid.org/0000-00027538-8965.

Yagup Valerii, Doctor of Technical Sciences, Professor, Department of Systems and Electric Power Supply of Cities, O. M. Beketov National University of Urban Economy in Kharkiv.E-mail: yagup.walery@gmail.com. ORCID: http://orcid.org/0000-0002-7019-3499.

Bozhko Volodimir, Candidate of Technical Sciences, Department Chief, Department of railway infrastructure and traction, Branch "Design and survey institute of railway transport" of Public Joint-Stock Company “Ukrainian zaliznytsia”. E-mail: bozhkovv81@gmail.com. ORCID: http://orcid.org/0000-0001-6068-2881. 